\title{
Didactic Competencies among Teaching Staff of Universities in Kenya
}

\author{
Florah Katanu Karimi ${ }^{1}$ \\ ${ }^{1}$ Commission for University Education, Kenya \\ Correspondence: Florah Katanu Karimi, Commission for University Education, Kenya. E-mail: \\ florahkarimi@gmail.com
}

Received: January 9, 2014

Accepted: February 17, 2014

Online Published: March 3, 2014

doi:10.5430/ijhe.v3n2p28

URL: http://dx.doi.org/10.5430/ijhe.v3n2p28

\begin{abstract}
The aim of this study was to establish the levels and types of didactic competencies that exist among teaching staff in universities in Kenya, giving recognition to curriculum development, pedagogical attributes and quality assurance competencies. The study was carried out in two phases among two samples of the teaching staff population. The first sample consisted of 229 randomly sampled teaching staff from three public chartered universities in Kenya while the second sample consisted of 46 teaching staff who had been engaged in quality assurance activities of the university education national quality assurance agency in Kenya. The methodology entailed analyzing the curriculum vitae of the first sample for purposes of determining the teaching staff's consideration of didactic competencies as an achievement area in their teaching profession and thereafter analyzing the responses of the second sample to an open-ended questionnaire in order to determine the teaching staff's acquired and needed didactic competencies. The results revealed that a low percentage of teaching staff (37.1\%) considered didactic competencies as an achievement area in the teaching profession. On the other hand, didactic competencies in pedagogical attributes were highly regarded as compared to those in curriculum development and quality assurance. There was need for advocacy and sensitization of teaching staff and university management on the importance of the three types of didactic competencies in the enhancement of the quality of teaching and learning at the university. In addition, taking cognizance of the dynamism in education, teaching staff needed to keep abreast with the paradigm shifts through regular training and retraining on the various types of didactic competency areas.
\end{abstract}

Keywords: Didactic competencies, Teaching staff of universities, Curriculum development, Pedagogical attributes, Quality assurance

\section{Introduction}

The last two decades have experienced global rapid increase in the demand for university education, which has been attributed to economic and political development, competitiveness in the global society; and capacity building in support of the Millennium Development Goals (MGDs)(Materu, 2007). The UIS (2011) depicted the global student population as having increased by $143 \%$ over a 18 -year span running from the year 1991 (68 million students) to the year 2009 (165 million students). More specifically, the Kenya National Bureau of Statistics, depicts a 91\% increase in the student population in universities in Kenya over a 6-year period from the academic year of 2005/06 (95,283 students) to 2010/2011 (182,253 students). The growth in student population in universities in Kenya has resulted in an increase in the demand for more institutions offering university education. The website of the Commission for University Education (CUE), which is the university educationnational quality assurance agency in Kenya, revealed an increase in the number of recognized universities in Kenya from 24 in the year 2008 to 66 in the year 2013, which is a $175 \%$ increment over a 5 -year span.

With the global rapid increase in student population and universities there has been an increased demand for mechanisms to ensure quality university education. According to the Commission of the European Communities (2009) institutions offering university education needed to establish internal quality assurance structures to monitor and enhance quality in their institutions while developing a quality culture. The European efforts towards quality assurance called for qualified and competent teaching staff in order that the quality of education would be enhanced and comparable across the region (European Science Foundation, 2012). According to Altbach, Reisberg and Rumbley (2009), universities needed to prioritize teaching and student learning in order to compete in a global knowledge market, Teacher development programmes had been developed in a number of European countries (European Science 
Foundation, 2012). This initiative hasspread globally to other countries out of the region including the United States, Australia and Canada.

Materu (2007) observed that African countries were taking cognizance of the need for quality assurance and improvement at tertiary levels of education, an observation that is supported by the fact that at least twenty countries in Africa had national agencies for quality assurance (Association of African Universities, 2012). In Kenya, quality assurance of university education entails accreditation and external quality assurance initiatives of universities and academic programmes by the national quality assurance agency, CUE, and development of internal quality assurance structures by universities (Commission for Higher Education, 2008), in line with the Universities Act, No. 42 of 2012. There had also been a move towards institutionalization of quality assurance in the East African region under the auspice of the Inter-University Council for East Africa (IUCEA) in collaboration with the national quality assurance agencies and the universities in the region (The Inter-University Council for East Africa, 2010).

The Inter-University Council for East Africa (2010) regional handbooks on quality assurance in higher education considered the quality of the teaching staff to be a vital indicator of quality university education, with focus being given to educational activities, research and community engagement. With global attention being given to, not only competencies of teaching staff in subject matter, but also to didactic competencies which influence educational activities, it is inevitable that Kenya gives the needed attention to the latter competencies. Universities' job advertisements in Kenya revealed academic qualifications, teaching experience, research, publications and attendance of conferences, seminars and workshops to be prerequisites to teaching at the university. However, little emphasis is given to the didactic competencies required at the university.

In order to determine the didactic competencies that exist among the teaching staff of the universities in Kenya, thus provide direction to the development of institutional policies and practices for teaching staff in the universities, the study sought to answer the research questions:

1) What is the portrayedlevel of didactic competencies among the teaching staff of universities in Kenya?

2) What types of didactic competencies exist among the teaching staff of the universities in Kenya?

3) What types of didactic competencies are perceived asneeded among the teaching staff of universities in Kenya?

\section{Professional competencies among teaching staff in the universities}

\subsection{Paradigm shift in education}

Education comprises of teaching and learning, both of which are considered to be basic and distinct processes in education and complementary to each other (Sah, 2012; Long, Ibrahim \&Kowang, 2014). Education has experienced a pedagogical shift, in the $21^{\text {st }}$ century, from being teacher-centered to student-centered. There has also been an increased importance given to constructivism, which emphasizes learning as a result of meaningfulness to the learner (Zuljan, 2007; Gilis, Clement, Laga, \&Pauwels, 2008; Sah, 2012) and incorporation of new understanding and knowledge into old understanding and knowledge (Fry, Ketteridge\& Marshall, 2009). Other changes that have been experienced in education and that have contributed to the need for continual professional development of teaching staff include the context of practice; re-defined roles for both teaching staff and students; and the development and maintenance of levels of competencies among teaching staff (Frick \&Kapp, 2006).

Many universities have shifted focus from passive learning, which relates to surface learning approaches, to active learning, engaging students in deep approaches to learning (Case \& Marshall, 2009; Kember, 2009). Independent, creative and critical thinking has been encouraged among the students. The students' learning outcomes have been considered to depend on their own effort and activities, which they direct and are responsible for (Zuljan, 2007; Gilis et al., 2008; Maggioni\& Parkinson, 2008; Sah 2012). On the other hand, the role of the teaching staff has shifted to one of providing support to the student in their learning process and creating a learning environment oriented towards deep learning approaches (Gilis et al., 2008; Case \& Marshall, 2009; Fry et al., 2009; Long et al., 2014).

\subsection{Teaching as a profession}

Teaching influences students' learning and is considered to be a profession requiring specialized knowledge acquired through both training and experience (World Health Organization, 2002; Ololube, 2006; Slavin, 2006; Anantadjaya\&Nawangwulan, 2007; European Commission, 2008; Matzler\&Woessmann, 2010; Thapa, 2012; Long et al., 2014). Thus, the professional competencies of the teaching staff are essential to the enhancement of education at all level. According to the Inter-University Council for East Africa (2010), the quality of teaching staff depended on the latter's ability to achieve the goals, objectives and learning outcomes of academic programmes, which in turn are 
influenced by the staff's engagement in teaching, research and community outreach, all of which are critical to enhancing their academic development (Rowland, 2006).

The importance of teaching competenciesamong teaching staff is often downplayed as compared to that of research competencies, with the latter, and not the former, often being considered as a criterion for career advancement at the university. Observations revealed that in Europe in particular, academics were not as prepared for their teaching career as they were for research (European Science Foundation, 2012). According to Acker and Haque (2010) in Canada, competencies in production of publications were of greater concern to doctoral students who were teaching in the university as compared to competencies in teaching, which were considered to be attainable through experience on the job. Berthiaume (2009) also observed that teaching staff in higher education were trained for many years in their subject area and research and, in most cases, not at all in teaching, yet teaching occupied the teaching staff most in their academic career. University teaching staff developed their understanding of teaching and learning either on their own or through the older teaching staff (Berthiaume, 2009; Austin, 2010). Taking cognizance of the Bologna process that recognized the need for improved teaching, the European Higher Education Areahas made the development of teaching skills among teaching staff a priority. This endeavor is being adopted in other areas of the world.

\subsection{Teaching competencies}

Teaching competencies are an integration of professional attitudes, knowledge and skills and enable the individual to fulfil his/her role and effectively influence the students' learning process (Veal \&Makinster, 1999; Gilis, Clement, Laga\&Pauwels, 2008; Thapa, 2012; Long, Ibrahim \&Kowang, 2014). Three types of teaching competencies that have been greatly considered by various authors are professional attitudes, didactic competencies and subject matter competencies (Shulman, 1986; Gilis, et al., 2008; Liakopoulou, 2011).

Professional attitudes relate to teaching, student management and team-playing, all of which are enhanced through experience (Gilis, et al., 2008, Liakopoulou, 2011). On the other hand, didactic competencies require training beyond experience. Didactic competencies can be categorized under a plan-do-check cycle of designing, delivering and quality assurance of education (Gilis, et al., 2008), which are also alluded to by Peterson \&Tonnesen (2006) who categorize didactic competencies as competencies in curriculum development, teaching and evaluation and reflection of education.In the didactic competency areas, planning relates to curriculum designing and development and includes course and module designing. Curriculum planning and knowledge is considered to be essential to the teaching profession (Shulman, 1986; Turner-Bisset, 2003; Liakopoulou, 2011).

According to Shulman (1986), curriculum and its associated materials are prerequisites to pedagogy, which relates to the content delivery. Consequently, the doing competencies comprise of pedagogical skills, classroom management assessment, context, environment, nature of discipline and socioculturalism, all of which are inter-related (Shulman, 1986; Veal \&Makinster 1999) and can generally be considered as pedagogical attributes. Teachers in Greece recognizepedagogical knowledge as a significant qualification to the teaching profession (Liakopoulou, 2011), a perspective that should be adopted even in Kenya. On the other hand, the checking competencies relate to evaluation and reflection, which are quality assurance aspects and, among other aspects, assess the capabilities of the professionals (Shulman, 1986). Thus, this study considers the plan-do-check cycle of didactic competencies as entailing curriculum design and development; pedagogical attributes; and quality assurance.

Another teaching competency area is that of subject matter, which is associated with content-related expertise. Beyond the knowledge of the subject matter, there is need for the teaching staff to develop pedagogical approaches to the specific subject matter (Shulman, 1986; Liakopoulou, 2011). Thus, subject-based pedagogical attributes are vital to the teaching profession.

In general, professional attitudes of teaching staff and subject matter competencies are prioritized in the academic career advancement of teaching staff in Kenya. However, little is known of the attention given to didactic competencies among teaching staff of the university. This study sought to establish the portrayedlevel of didactic competencies among teaching staff of the university. The study further sought to establish the types of and needsfor didactic competencies among the teaching staff, taking cognizance of the plan-do-check cycle categories of curriculum development, pedagogical attributes and quality assurance.

\section{Methodology}

The study was descriptive in nature and comprised of two phases. The first phase sought to establish the levels of didactic competencies among the teaching staff of the universities while the second phase sought to establish the specific types of didactic competencies that existed and the perceived didactic competencies needed by the teaching staff of universities in Kenya. 
The study sample was drawn from teaching staff of the universities in Kenya. Purposive sampling techniques were employed in the study. In the first phase of the study, 229 teaching staff were randomly selected from websites of three out of seven randomly sampled public universities that had been in existence in the country for more five years and thus had graduated more than two cohorts of students. The selected universities were Kenyatta University, University of Nairobi and Jomo Kenyatta University of Agriculture and Technology. The choice of teaching staff from public universities was informed by the fact that, according to the Kenya National Bureau of Statistics surveys, students' enrolment into public universities constituted more than $80 \%$ of the total enrolment into the universities in Kenya. Thus, the effect of teaching on learning, and thus on the labour market and the society at large, would greatly reflect learning from the public universities viewpoint as compared to that of the private universities in Kenya.

The sample used in the second phase of the study comprised of a selection from 180 teaching staff who were engaged in activities at the national quality assurance agency. The latter were teaching staff whose email addresses were accessible at the national quality assurance agency, the CUE. They were teaching staff who had been exposed to various aspects of quality assurance in university education and were perceived to be able to provide meaningful information to the study. The teaching staff were also considered by the national quality assurance agency to be experts in their academic fields and thus able to provide the much needed direction with regard to quality university education. In the latter scenario, only the 46 teaching staff who responded to the data collection instrument were considered as part of the study's sample.

The data was obtained from both primary and secondary sources. The secondary source of data comprised of the curriculum vitae of the 229 teaching staff of the public universities. The choice of the curriculum vitae as a secondary source of data was informed by the former's ability to provide a summary of the teaching staff's qualifications and achievements as professed by the teaching staff. The curriculum vitae of the teaching staff were studied and an indication of those that reflected didactic skills as part of their qualifications or achievements obtained. Primary data was obtained from responses to an open-ended questionnaire that was emailed to the teaching staff who had been engaged in quality assurance endeavours of the CUE. The items in the questionnaire focused on the perceived presence of didactic competencies, source of acquired didactic competency, trainings received on didactic competencies and didactic competencies' needs among the teaching staff.

The data obtained in the two phases of the study was coded and analyzed using descriptive statistics, namely, frequencies and percentages through use of the Statistical Package of Social Statistics (SPSS) and further refined using Microsoft Excel 2010.

\section{Results and discussions on didactic competencies among public university teaching staff in Kenya}

\subsection{Didactic competencies among public university teaching staff}

Analysis of the data obtained from the curriculum vitae of teaching staff of public universities in Kenya depicted 85 out of $229(37.1 \%)$ teaching staff as professing didactic competencies as an achievement in their career development. The results portrayed a possibly low recognition of the importance of didactic competencies as a contributor to their professional growth as teaching staff. In particular, the results may have been an indicator that the teaching staff either did not perceive theirteaching competencies as important aspects of their professional achievements or did not have the didactic competencies.

Theteaching staff who had didactic competencies reported having attended training courses in training of trainers (TOT) $(24.7 \%)$, curriculum development (18.8\%), pedagogy (62.4\%), e-learning (37.6\%), communication skills $(15.3 \%)$, course and module development (16.5\%), supervision skills (7.1\%), student assessment $(11.8 \%)$ and quality assurance $(2.4 \%)$ as reflected on Graph 1. 


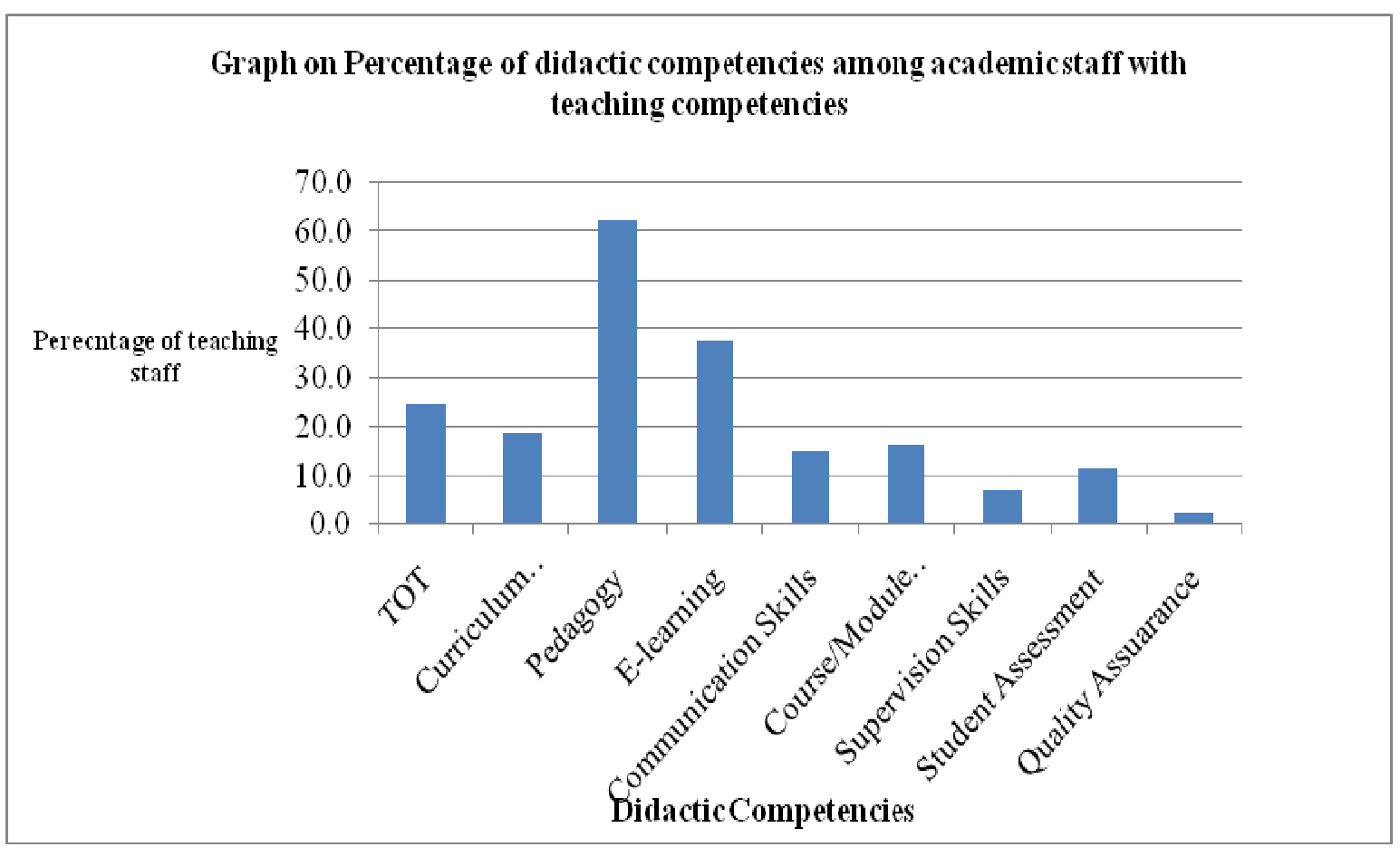

Graph 1. Percentage of competencies among teaching staff with didactic competencies

Graph 1 depicts the highest percentage of teaching staff with didactic competencies as having skills in pedagogy (62.4\%). This is followed by e-learning skills (37.6\%) and the least as quality assurance (2.4\%). The results can be categorized into the three didactic competency plan-do-check cycle areas of planning, which relates to courses in curriculum and course/module development; doing, which includes training of trainers (TOT), e-learning, communication skills, pedagogy, supervision skills and student assessment skills courses and are considered in this study to be pedagogical attributes; and checking, which relates to quality assurance courses.

Using the plan-do-check cycle, the didactic competencies were further categorized and analyses in the three categories of curriculum development, pedagogical attributes and quality assurance. The results revealed that twenty three (26.7\%) of the teaching staff who had didactic competencies had received training in curriculum, course and/or module development, eighty (93\%) had received trainingin pedagogical attributes and two (2.4\%) had received training in quality assurance aspects. Thus, the majority of the teaching staff who indicated didactic competency training had received the training in pedagogical areas.

Information gathered from teaching staff engaged in quality assurance endeavors of the national quality assurance agency depicted the former's didactic competencies as having been acquired through first, further training (77.8\%), then academic qualifications (71.1\%) and lastly experience (55.6\%). The high appreciation of didactic competencies among teaching staff in this second sample as compared to the first sample may be attributed to the former's greater exposure to quality assurance requirements as compared to the latter one's. Thus, the affinity for quality improvement among the teaching staff who had been involved in the quality assurance endeavors of the CUE may be considered higher than that of the rest.

4.2 Didactic competencies among teaching staff who were involved in external quality assurance endeavors

Analysis of the perceived didactic competencies among the teaching staff of the second level sample revealed that more than $50 \%$ of the teaching staff considered themselves as having teaching profession competencies in their subject area $(64 \%)$, teaching techniques $(60 \%)$ and generally in pedagogical areas $(71 \%)$ as presented on Graph 2. 


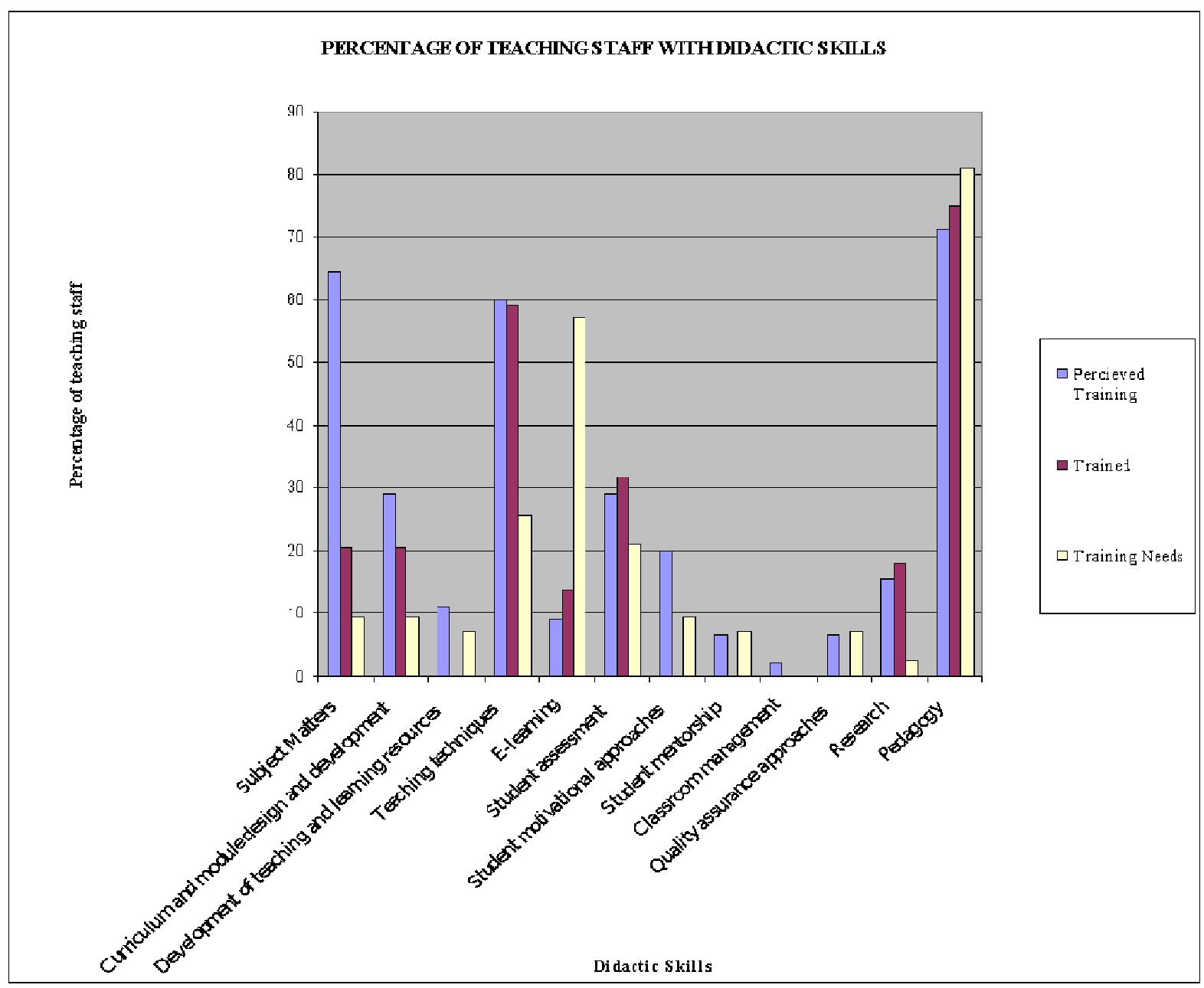

Graph 2. Percentage of teaching staff with didactic skills

The pedagogical attributes competencies included development of teaching and learning resources, teaching techniques, e-learning techniques, student assessment, student motivation approaches, student mentorship and classroom management. The graph depicts a higher percentage of teaching staff $(75 \%)$ having been trained in pedagogical attributes competency areas but a lower percentage of perceived didactic competencies $(71 \%)$. This could be a reflection of lack of confidence among the teaching staff of their pedagogical attributes competencies. This hypothesis is further supported by the higher percentage of teaching staff that portrayed a need for further training on pedagogical attributes competency areas (81\%).

One area of the pedagogical attributes competencies that the teaching staff reflected a need for was that of e-learning $(57 \%)$. This need would be expected, taking cognizance of the low percentage of teaching staff who perceived themselves as being competent ( $9 \%$ ) with only $6 \%$ having been trained on the same; the rapid change in the delivery methods in favor of electronically delivered teaching techniques; and the global embrace of Open, Distance and E-learning (ODEL).

With regard to the subject area, $20 \%$ of the teaching staff had received further training on the subject area. This implied that $44 \%$ of the teaching staff acquired their competencies in the subject matter through experience and academic qualification. In addition, 9\% of the teaching staff reflected a need for further training in the subject area competencies, an indication of an attitude of contentment in the teaching staff's subject area competencies and thus towards upgrading competencies in the subject area.

A low need for further training in teaching techniques (26\%) was also expressed. This could be attributed to the teaching techniques training received by a high number of teaching staff $(59 \%)$.Areas whereby less than half of the teaching staff reflected having competencies and training in and yet having no need for training included curriculum 
and course and module development, development of teaching and learning resources, student assessment techniques, student motivation approaches, student mentorship, classroom management and quality assurance approaches. This could be perceived as a lack of appreciation of these didactic competency areas as being of importance in enhancing the teaching staff's careers and student learning.

\section{Conclusions and recommendations on didactic competencies among teaching staff of universities in Kenya}

\subsection{Levels of didactic competencies among teaching staff of the universities in Kenya}

The study depicted a low recognition of the need for didactic competencies as an achievement areaamong the teaching staff of the universities in Kenya. These results corresponded with the observations made by Berthiaume (2009), Austin (2010) and Nakpodia (2011) who considered professional competencies of teaching staff in the universities as having being poorly considered as a requirement for academic career advancement among teaching staff of the university. Taking cognizance of the amount of time dedicated to teaching in the university, the didacticcompetencies of teaching staff should be enhanced. Advocacy among the teaching staff and the universities management on the need for enhanced didactic competencies should be made.

University policies need to include aspects that are geared towards teaching effectiveness including the enhancement of didactic competencies among teaching staff of the universities. More specifically, the policies on didactic competencies should enhance the plan-do-check cycle of competencies, namely, curriculum development, including course and module development; pedagogical attributes; and quality assurance competencies.

Didactic competencies required for teaching at the university education level differ from those required for lower education levels. This implies that, in order to be effective in teaching in the university, the teaching staff need training in didactic competencies geared towards enhancement of learning at the university. Moreover, the $21^{\text {st }}$ century pedagogical shift requires of teaching staff to be re-trained in order to be able to effectively address the current needs of university education. Teaching staff, therefore, need to be sensitized on the need for enhanced didactic competencies, which are not only influences by practice but greatly by training. This would contribute to a change of attitudes on didactic competency enhancement.

Mechanisms should be put in place to motivate the teaching staff to acquire didactic competencies. First and foremost, there is need for the management of the universities to support the continual professional development of its teaching staff (Frick \&Kapp, 2006). Universities'management need to consider introducing comprehensive training programmes on didactic competencies for the teaching staff of the university. These programmes should comprise of training in all the three plan-do-check didactic competency categories of curriculum development, pedagogical attributes and quality assurance. Every teaching staff of the university should be compelled to participate in the didactic competency training programmes of the university. In addition, consideration should be given to modifying the job recruitment and advancement requirements to include aspects of didactic competencies. Training on didactic competencies should also be considered as part of the universities' teaching staff induction programmes.

\subsection{Types of didactic competencies}

Curriculum and course or module development is an integral part of university education in Kenya. The low appreciation of the need for competencies in curriculum development and course and module development among teaching staff of the university reveals the need for more advocacy to be done with respect to the planning competency areas and greater support to be given by the university to the training of staff on the same. Whereas curriculum at lower educational levels is developed nationally, that at the university level of education is developed by teaching staff of individual universities. Thus, the development of the curriculum is crucial to determining the outcomes of the academic programme. Curriculum is supported by course and module plans, all of which should be well developed. Thus, the need for competencies among the teaching staff in curriculum and course and module development is critical to the success of any academic programme in the universities in Kenya. In view of the paradigm shift in education, curriculum models that promote learner-centredapproaches, and thus more of student-control rather than teacher-control over learning, should be adopted in the training programmes.

Pedagogical attributes differ from discipline to discipline (Berthiaume, 2009). In addition to general pedagogicalattributes that all teaching staff should be exposed to, there is need for the latter to be exposed to pedagogical attributes specific to their subject matter. The various academic departments of the universities should expose their teaching staff to specific subject matter-related pedagogical attributes. Taking cognizance of the dynamism in education, there is need for the teaching staff to keep abreast with the changes in didactic skills and to participate in refresher courses that would enhance their teaching, taking cognizance of the general changes in education and their specific academic disciplines. This view is further supported by that of Materu (2007) who pointed 
out that there was need for universities to adjust their programme structures, curriculum and teaching and learning methods in order to meet the new demands of competencies, which include adaptability, team work, communication skills and motivation, more so for continual education. There is a strong link between teaching, learning and assessment (Sah, 2012). Thus, in order to ensure that the results obtained from a learning process are reliably and validly reflected, it is critical that attention be given to the assessment of students learning, as well as to teaching and learning. Teaching staff in the university, thus, should be exposed to the competenciesthat enhance teaching, learning and student assessments. The need for specific training on e-learning techniques and requirements, taking cognizance of the paradigm shift in the use of electronic techniques of delivery of both academic programmes and courses and the effects of globalization, cannot be downplayed.

The global expansion of university education and increased pressure on universities to enhance economic and social development has called for efficiency and effectiveness in university education systems, thus leading to the demand for quality assurance for purposes of accountability and quality enhancement (EHEA, 2012). According to Liakopoulou, (2011), there was need for a professional competency framework of evaluation of teaching. Course and programme evaluation is a vital component of determining the effectiveness of instruction in influencing the students' learning, thus can be considered as a quality assurance mechanism of teaching and learning. A study to critique the methods used to evaluate the competencies of lecturers in Nigerian tertiary institutions carried out by Nakpodia (2011) revealed one of the weaknesses of the instrument as that of giving little focus to the competencies in teaching, despite excellence in academia first requiring of excellence in teaching. According to Nakpodia, more focus was given to aspects such as main duties, researches, ad-hoc duties, scholarly activities such as seminar, conferences, workshops, and courses attended and, publications at the expense of competencies in teaching. One of the most strongly validated, robust and reliable instrument for evaluating students' experiences in courses and programmes of study internationally is the Course Experience Questionnaire (CEQ), which was developed by Ransden in 1991 as a performance indicator for monitoring the quality of teaching on individual academic programmes at Australian universities (Barrie \&Ginns, 2007; Richardson, 2009). The questionnaire consisted of thirty items in five scales, which were notably the 'good teaching', 'clear goals and standards', 'appropriate workload', 'appropriate assessment' and 'emphasis on independence' scales. Taking cognizance of good practices, programme and course evaluation instruments in the universities should be designed in a manner that reflects the five scales of CEQ. Results of such evaluation instruments should be effectively utilized in enhancing the professionalcompetencies of the teaching staff of the university. Teaching staff, therefore, need training on the designing and effective utilization of course and programme evaluation tools. Taking cognizance of the poor perception of teaching staff on the need for competencies in quality assurance mechanisms, there is need for great advocacy and support to be given to quality assurance in university education.

\section{References}

Acker, S. \& Haque, E. (2010). Doctoral students and a future in academe. In L. McAlphine\& G. Akerlind (eds.) Becoming an academic: International perspective, 96-124, United Kingdom: Palgrave Macmillan.

Altbach, P. G., Reisberg, L. \& Rumbley, L. E. (2009). Trends in global higher education: Tracking an academic revolution. A report prepared for the UNESCO_2009 World Conference on Higher Education. France: UNESCO. [Online] Available: Unesdoc.unesco.org/images/0018/001831/183168.

Association of African Universities. (2012). The quality assurance situation and capacity building needs of higher education in Africa. Ghana: AAU.

Anantadjaya, S. P. D. \& Nawangwulan, I. M. (2007). Lecturer Competencies: A case study in international universities. JurnalSistemInformasi2 (1) 11-20. [Online] Available: papers.ssrn.com/sol3/papers.cfm.

Austin, A. E. (2010). Expectations of aspiring and early career academics. In L. McAlphine\& G. Akerlind (eds.) Becoming an Academic: International perspective, 18-44, United Kingdom: Palgrave Macmillan.

Barrie, S. \&Ginns, P. (2007). The linking of national performance indicators to improvements in teaching and learning in classrooms. Quality in Higher Education, 13 (3), 275-286. http://dx.doi.org/10.1080/13538320701800175

Berthiaume, D. (2009). Teaching in the discipline. In H. Fry, S. Ketteridge and S. Mashall (eds.) A handbook for teaching and learning in higher education: Enhancing academic practice. $3^{\text {rd }}$ Ed., 215-225, New York: Taylor and Francis.

Case, J. M. \& Marshall, D. (2009). Approaches to learning.In M. Tight, K. H. Mok, J. Huisman\& C. C. Morphew. (eds.)The Routledge International Handbook of higher education, 9-21, New York: Taylor and Francis. 
Commission for Higher Education. (2008). Handbook on processes for quality assurance in higher education in Kenya. Kenya: Commission for Higher Education.

Commission for University Education (2014). Status of Universities in Kenya. [Online] Available: http://www.cue.or.ke.

Commission of the European Communities. (2009). Report on progress in quality assurance in higher education. Brussels.

EHEA. (2012). Beyond the Bologna process: creating and connecting national, regional and global higher education areas.Background paper on the third Bologna Policy Forum, April, 27th 2012, Bucharest. [Online] Available: www.ehea.info.

European Commission. (2008). Higher education governance in Europe: Policies, structures, funding and academic staff. Belgium, Brussel: Eurydice. [Online] Available: eacea.ec.europa.eu/education.

European Science Foundation. (2012). The professionalisation of academics as teachers in higher education: Science position paper. France: Ireg Strasbourg. [Online] Available: www.esf.org/social.

Fry, H., Ketteridge, S. \& Marshall, S. (2009). Understanding student learning. In H. Fry, S. Ketteridge and S. Mashall (eds.) A handbook for teaching and learning in higher education: Enhancing academic practice. $3^{\text {rd }}$ Ed., 8-26, New York: Taylor and Francis.

Frick, 1. \& Kapp, C. (2006). Future trends in continuing professional development for natural science lecturers in higher education: Survival of the fittest in the academic jungle. In Experience of Learning.Proceedings of the $15^{\text {th }}$ Annual Teaching Learning Forum, 1-2 February 2006. Perth. The University of Western Australia. [Online] Available: http://lsn.curtin.edu.au/professional_development/conference/tlf/tlf2006/refereed/frick.html.

Gilis, A., Clement, M., Laga, L. \& Pauwels, P. (2008). Establishing a competence profile for the role of student-centered teachers in higher education in Belgium.Research in Higher Education, 49, 531-554. http://dx.doi.org/10.1007/s11162-008-9086-7

Kember, D. (2009). International Students from Asia.In M. Tight, K. H. Mok, J. Huisman\& C. C. Morphew. (eds.)The Routledge International Handbook of higher education, 47-60, New York: Taylor and Francis.

Kenya National Bureau of Statistics website. [Online] Available: www.knbs.or.ke.

Liakopoulou, M. (2011). The professional competence of teachers: Which qualities, attitudes, skills and knowledge contribute to a teacher's effectiveness? International Journal of Humanities and Social Science, 1 (21), 66-78. [Online] Available: www.ijhssnet.com/journals/vol_1_no_21_SpecialIssue.

Long, C. S., Ibrahim, Z. \&Kowang, T. O (2014). An analysis on the relationship between lecturers' competencies and students' satisfaction.International Education Studies, 7 (1), 37-46. www.ccsenet.org.

Maggioni, L. \& Parkinson, M. M. (2008). The role of teacher epistemic cognition, epistemic beliefs, and calibration in instruction. Educational Psychology Review, 20, 445-461. http://dx.doi.org/10.1007/s10648-008-9081-8

Materu, P. (2007). Higher education quality assurance in Sub-Saharan Africa: Status, challenges, opportunities and promising practices. Washington, D. C.: The World Bank. http://dx.doi.org/10.1596/978-0-8213-7272-2

Matzler, J., \&Woessmann, L. (2010). The impact of lecturer subject knowledge on student achievement: Evidence from within-lecturer within-student variation. The Institute for the Study of Labor. [Online] Available: http://ftp.iza.org/pd4999.pdf

Nakpodia, E. D. (2011). A critique of the methods of evaluating the competency of lecturers in Nigerian Tertiary Institutions.African Journal of Education and Technology, 1 (1), 53-59. [Online] Available: sachajournals.com/documents/NakpodiaAJET008A.pdf.

Ololube, N. P. (2006). Teacher Education, school effectiveness and improvement: A study of academic and professional qualification on teacher job effectiveness in Nigerian secondary schools. An academic dissertation presented to the Faculty of Behavioral Science at University of Helsinki. [Online] Available: ethesis.helsinki.fi/julkaisut/kay/sovel/vk/ololube/.

Peterson, P. M. \& Tonnesen, L. G. (2006). Teaching didactic issues in ODL. In Jens Vermeersch (ed) Getting started with ODL, 57-68, Belgium. [Online] Available: www.odlexpert.net/iaml3/getstart/chapter5.pdf.

Ramsden, P. (1991). A performance indicator of teaching quality in higher education. The Course Experience Questionnaire.Studies in Higher Education, 16, 129-150. http://dx.doi.org/10.1080/03075079112331382944 
Richardson, J. T. E. (2009). What can students' perceptions of academic quality tell us? Research using the Course Experience Questionnaire.In M. Tight, K. H. Mok, J. Huisman\& C. C. Morphew. (eds.)The Routledge International Handbook of higher education, 119-210, New York: Taylor and Francis.

Rowland, S. (2006).The Enquiring University: Compliance and contestation in higher education. Buckingham: Open University Press.

Sah, K. P. (2012). Assessment and Test in Teaching and Learning. A Multidisciplinary Journal, 2 (1), 28-32.nepjol.info > ... > Vol 2 (2012) > Sah.

Slavin R. (2006). Educational Psychology: Theory and Practice ( $8^{\text {th }}$ Ed.) Needham Heights, MA: Allyn and Bacon.

Shulman, L. S. (1986). Those who understand: Knowledge growth in teaching. Educational Researcher, 15 (2), 4-14. http://dx.doi.org/10.3102/0013189X015002004

Thapa, T. B. (2012). Transfer of teacher training skills in classroom. A Multidisciplinary Journal, 2 (1), 69-73. [Online] Available: www.nepjol.info/index.php/AV/article/download/8292/6760

The Inter-University Council for East Africa. (2010). A road map to quality: Handbook for quality assurance in higher education. Vol. I. Uganda: Inter-University Council for East Africa.

The Inter-University Council for East Africa. (2010). A road map to quality: Handbook for quality assurance in higher education. Vol. II. Uganda: Inter-University Council for East Africa.

Republic of Kenya. (2012). The Universities Act, 2012. Nairobi: Government Printer

Turner-Bisset, R. (2003). Expert teaching: Knowledge and pedagogy to lead the profession. London: David Fulton Publishers.

UIS. (2011). Global education digest, 2011: Comparing education statistics across the world. Montreal: UNESCO Institute of Statistics.

Veal, W. \& Makinster, J. (1999). Pedagogical content knowledge taxonomy.Electronic Journal of Science Education, 3 (4). [Online] Available: http://wolfweb.unr.edu/homepage/crowthr/ejse/vealmak.html.

World Health Organization. (2002). Accreditation guidelines for education/training institutions and programmes in Public Health. A report of the regional consultation held in Chennai, India on the $30^{\text {th }}$ January $-1^{\text {st }}$ February 2002. [Online] Available: apps.searo.who.int/pds_docs/B3430.pdf.

Zuljan, M. V. (2007). Students' conceptions of knowledge, the role of the teacher and learner as important factors in the didactic school reforms. Education Studies, 33 (1), 29-40. http://dx.doi.org/10.1080/03055690600948166 